\title{
IRRIGATION SCHEDULING OF WHEAT AT DIFFERENT NITROGEN LEVELS IN SEMI-ARID REGION
}

\author{
Muhammad Usman BASHIR ${ }^{1,2^{*}}$, Syed Aftab WAJID ${ }^{l}$, Ashfaq AHMAD ${ }^{l}$, Muhammad AWAIS ${ }^{1,2}$, \\ Muhammad Aown Sammar Raza ${ }^{2}$, Ghulam Mustafa TAHIR ${ }^{1}$,Umer SAEED ${ }^{l}$, Muhammad Habib Ur \\ REHMAN $N^{3}$, Muhammad WAQAS $S^{l}$, Shahid ABBAS \\ ${ }^{1}$ University of Agriculture, Department of Agronomy, Faisalabad, PAKISTAN \\ ${ }^{2}$ The Islamia University of Bahawalpur, Department of Agronomy, PAKISTAN \\ ${ }^{3}$ Muhammad Nawaz Shareef University of Agriculture, Department of Agronomy, Multan, PAKISTAN \\ *Corresponding author: usmanbashir2003@gmail.com
}

Received: 26.04.2016

\begin{abstract}
Appropriate nitrogen and optimum irrigation scheduling ensure economic yield. To access the behavior of development, growth and yield of wheat in response to nitrogen rates $\left(80,120\right.$ and $\left.160 \mathrm{~kg} \mathrm{ha}^{-1}\right)$ and irrigation scheduling, an experiment was conducted at Agronomy Research Area, University of Agriculture, Faisalabad using Randomized Complete Block Design in split plot arrangement. It was observed that accumulated thermal time and photo-thermal time derive the crop phenology. Calendar time of growth stages may vary depending upon the prevailing climatic conditions particularly minimum and maximum temperatures. Application of $120 \mathrm{~kg} \mathrm{ha}^{-1}$ nitrogen $\left(F_{2}\right)$ resulted in maximum LAI $(4.21 \& 4.73)$, mean crop growth rate $(9.38$ \& $\left.9.14 \mathrm{~g} \mathrm{~m}^{-2} \mathrm{~d}^{-1}\right)$, and grain yield ( $\left.3100 \& 3265 \mathrm{~kg} \mathrm{ha}^{-1}\right)$. Full irrigation performed better in terms of maximum LAI (4.97 \& 5.46), mean CGR (10.89 \& $\left.12.66 \mathrm{~g} \mathrm{~m}^{-2} \mathrm{~d}^{-1}\right)$ and grain yield (3735 \& $\left.4603 \mathrm{~kg} \mathrm{ha}^{-1}\right)$. Application of $120 \mathrm{~kg}$ Nitrogen ha ${ }^{-1}$ and full irrigation were found to be the best management practices for better growth and to attain maximum grain yield.
\end{abstract}

Keywords: Growth, Phenology, Triticum aestivum, Yield

\section{INTRODUCTION}

With increasing population, urbanization and limiting resources, agriculture sector is facing the challenge of more food production with less water (Liu et al., 2007). In developing countries, problem of water is acute and 37\% area of wheat growing regions is semi-arid (Karousakis and Koundouri, 2006). Water scarcity in Pakistan during Rabi season is about 3.3 million acre feet (GOP, 2014). With the variability in rainfall, situation sometime get worst. Wheat yield sustainability is highly dependent on water availability. There are two approaches to solve the issue of water shortage: engineering based approach (construction of water reservoirs) and agronomy based approach (on farm water management). Focusing on agronomy based solution, either we have to cultivate low water requiring crop or apply less water to the crop. Regulated deficit irrigation can be a possible option to get more crop per drop of water (Al-Harbi et al., 2015). It helps to reduce water consumption and minimize adverse effects on yield. Irrigating the crop only at drought sensitive growth stages and withheld water at other stages can help to manage water resources to meet crop requirement ( $\mathrm{Du}$ et al., 2010). Reduction in yield due to deficit irrigation can be compensated by the yield from additional irrigated area with the saved water. Ali et al. (2007) identified the stages tillering, stem elongation, booting, and grain formation as moisture sensitive stage in wheat crop.

Studies have revealed the increase in yield due to increase in nitrogen rate (Awais et la., 2017; Dumont et al., 2016) but it is not linear. So optimized rate of nitrogen, particularly in scenario of limiting water can help to sustain productivity as the loss of nitrogen due to leaching is dependent on availability of water and nitrogen management practices (Behera and Panda, 2009). This experiment was an attempt to study the response of wheat growth, phenology and yield to irrigation scheduling and nitrogen rate.

\section{MATERIALS AND METHODS}

Preset study was planned to access the performance of wheat for irrigation scheduling based on critical growth stages $\left(\mathrm{I}_{1}\right.$ : Irrigation at tillering, stem elongation, booting and grain formation; $I_{2}$ : Irrigation at stem elongation, booting and grain formation; $\mathrm{I}_{3}$ : Irrigation at tillering, stem elongation and grain formation; $\mathrm{I}_{4}$ : Irrigation at tillering, stem elongation and booting; $\mathrm{I}_{5}$ : Irrigation at tillering and stem elongation, and $\mathrm{I}_{6}$ : Irrigation at stem elongation and 
booting) and nitrogen rates $\left(\mathrm{N}_{1}: 80, \mathrm{~N}_{2}: 120\right.$ and $\mathrm{N}_{3}: 160$ $\mathrm{kg} \mathrm{N} \mathrm{ha}{ }^{-1}$ ) during Rabi seasons of two years 2010-11 and 2011-12. At the time of sowing, soil water contents were $33 \%$ and $32 \%$ in year 2010-11 and 2011-12 respectively. Experiment was conducted at Agronomic Research Area, University of Agriculture, Faisalabad situated in semi-arid agro-climatic conditions. Soil of the experimental area had sandy clay loam texture, organic matter $1.08 \%$ and $1.06 \%$, $\mathrm{pH} 7.64$ and 7.58, total soluble salts $12.29 \%$ and $12.26 \%$, Nitrogen $0.64 \mathrm{~g} \mathrm{~kg}^{-1}$ and $0.66 \mathrm{~g} \mathrm{~kg}^{-1}, \mathrm{P}_{2} \mathrm{O}_{5} 6.93 \mathrm{~g} \mathrm{~kg}^{-1}$ and $6.95 \mathrm{~g} \mathrm{~kg}^{-1}, \mathrm{~K}_{2} \mathrm{O} 19.4 \mathrm{~g} \mathrm{~kg}^{-1}$ and $19.0 \mathrm{~g} \mathrm{~kg}^{-1}$ for year 2010 11 and 2011-12, respectively.

Experiment was laid in Randomized Complete Block Design with split plot arrangement, keeping nitrogen in main plot and irrigation in sub plot, replicated thrice. Net plot size was $1.2 \mathrm{~m} \mathrm{X} 8 \mathrm{~m}$, with row-to-row distance of $20 \mathrm{~cm}$ and seed rate $125 \mathrm{~kg} \mathrm{ha}^{-1}$. Sehar-2006 was a promising test cultivar sown at mid-November. $90 \mathrm{~kg} \mathrm{ha}^{-1}$ phosphorus, $60 \mathrm{~kg} \mathrm{ha}^{-1}$ potash and half nitrogen were applied at the time of land preparation and second dose of nitrogen was applied at the time of irrigation at stem elongation. Starting from 45 days after sowing, six harvests for growth data were taken at the interval of 15 days. One meter long line was harvested at each sampling, (leaving appropriate boarder effect) from half of the plot for recording fresh and dry weight of leaves and stems. Leaf area meter (Cl-202) was used to determine the leaf area. LAI was calculated by formula assumed by Watson (1952):

\section{$\mathrm{LAI}=$ leaf area / land area}

Crop growth rate (CGR) was calculated by using the formulae given by Hunt (1978):

$$
\mathrm{CGR}=\left(\mathrm{W}_{2}-\mathrm{W}_{1}\right) /\left(\mathrm{t}_{2}-\mathrm{t}_{1}\right)
$$

All the developmental stages were defined when $50 \%$ of the plants showed visual signs of the stage being considered. Thermal Time (growing degree days) and photo-thermal time was calculated according to the Gallagher et al. (1983):

$$
\begin{aligned}
\mathrm{Tt} & =\mathrm{Tb}-(\mathrm{T} \min +\mathrm{T} \max ) / 2 \\
\mathrm{Tt} & =(\mathrm{T} \text { ave- } \mathrm{Tb}) *(\text { Pmean }-\mathrm{Pb}) /(24-\mathrm{Pb})
\end{aligned}
$$

$\mathrm{Tb}$ and $\mathrm{Pb}$ are the base temperature and base photoperiod which are $5{ }^{\circ} \mathrm{C}$ and 8 for wheat (FAO, 1978).

Final yield sample were harvested from second half of all the plots to record grain and biological yield. Data were analyzed by using Fisher's analysis of variance technique. To check the significance, treatment means were compared by using least significant (LSD) test at 0.05 probability level.

Data regarding weather parameters (maximum temperature, minimum temperature, rainfall) is presented in Fig 1 for both years. Amount of water applied to different treatmentrs and rainfall received during the

\begin{tabular}{|c|c|c|c|c|c|c|c|}
\hline Irrigation no. & Date & $\mathbf{I}_{1}(\mathrm{~mm})$ & $\mathbf{I}_{2}(\mathbf{m m})$ & $\mathrm{I}_{3}(\mathbf{m m})$ & $\mathrm{I}_{4}(\mathrm{~mm})$ & $\mathbf{I}_{5}(\mathbf{m m})$ & $\mathrm{I}_{6}(\mathrm{~mm})$ \\
\hline \multicolumn{8}{|c|}{$2020-11$} \\
\hline 1 & 15.12 .2010 & 75 & & 75 & 75 & 75 & \\
\hline 2 & 14.01.2011 & 75 & 75 & 75 & 75 & 75 & 75 \\
\hline 3 & 05.02 .2011 & 75 & 75 & & 75 & & 75 \\
\hline 4 & 05.03.2011 & 75 & 75 & 75 & & & \\
\hline Rain fall (mm) & & 28 & 28 & 28 & 28 & 28 & 28 \\
\hline Total (mm) & & 328 & 253 & 253 & 253 & 178 & 178 \\
\hline \multicolumn{8}{|c|}{ 2011-12 } \\
\hline 1 & 09.12 .2011 & 75 & & 75 & 75 & 75 & \\
\hline 2 & 14.01.2012 & 75 & 75 & 75 & 75 & 75 & 75 \\
\hline 3 & 10.02 .2012 & 75 & 75 & & 75 & & 75 \\
\hline 4 & 05.03 .2012 & 75 & 75 & 75 & & & \\
\hline Rain fall (mm) & & 24 & 24 & 24 & 24 & 24 & 24 \\
\hline Total (mm) & & 324 & 249 & 249 & 249 & 174 & 174 \\
\hline
\end{tabular}
growing season is given in Table.

Table 1. Amount of irrigation (I) applied and rainfall received by different irrigation treatments during 2010-11 and 2011-12. 

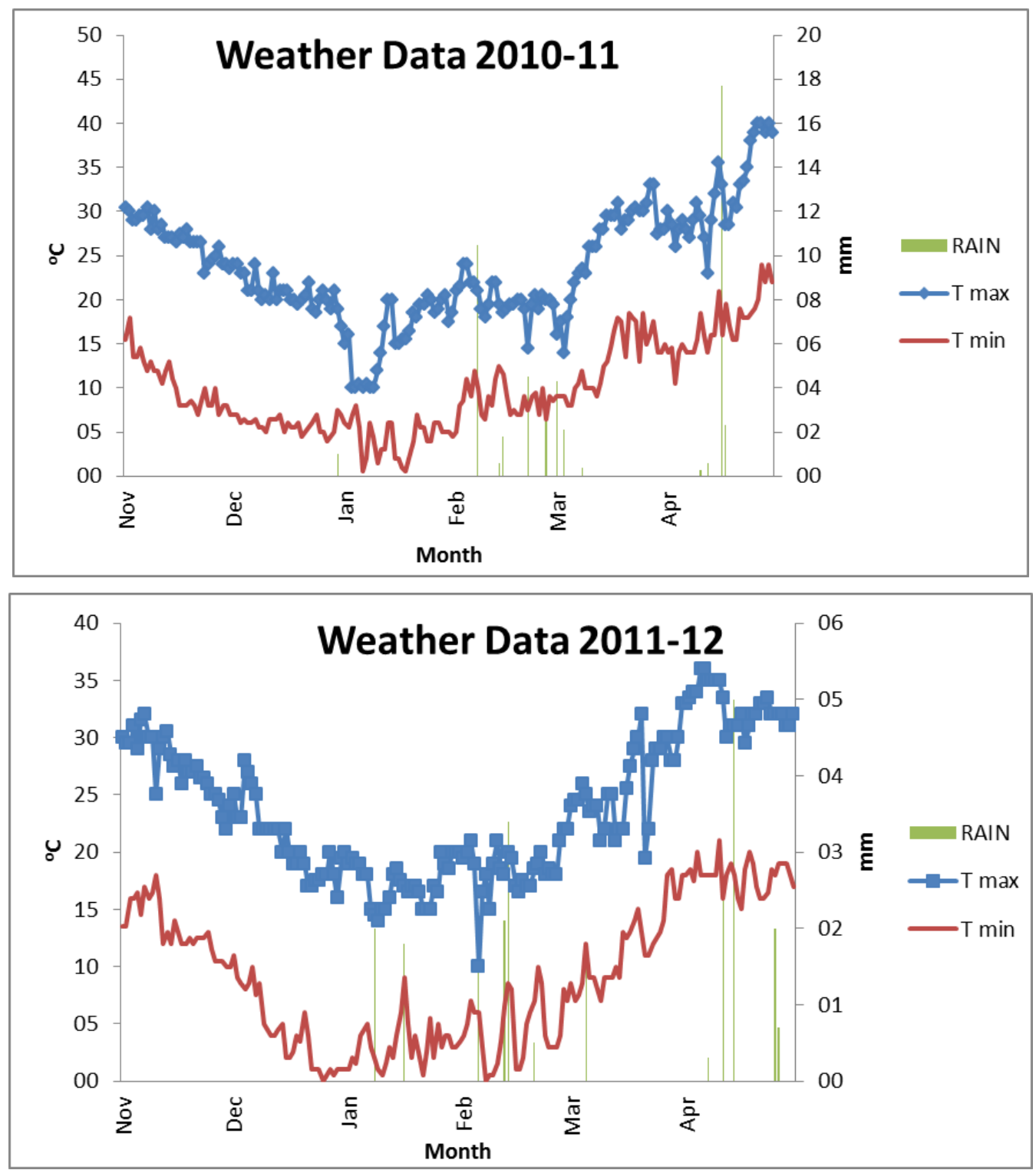

Figure 1. Summary of weather conditions at experimental site during 2010-11 and 2011-12

\section{RESULTS \\ Phenology}

Data in Table 2 indicates wheat phenology at no drought stress $\left(\mathrm{I}_{1}\right.$ : Irrigation at Tillering, Stem Elongation, Booting and Grain Formation) and high fertilizer rate $\left(\mathrm{F}_{3}\right.$ : $120 \mathrm{~kg}$ Nitrogen ha-1). Crop took 8 and 7 calendar days to germinate for year 2010-11 and 2011-12, respectively. Cumulated thermal time for germination was calculated to be 101 and 105 and photo-thermal time was recorded to be 14 and 15 for both years, respectively. Coefficient of variance for germination during both the years was $9.4 \%$ for calendar days and $2.8 \%$ for both thermal time and photo-thermal time.

Calendar days for emergence-tillering (E-T), tilleringstem elongation (T-SE), stem elongation-booting (SE-B) and booting-anthesis (B-A) were 22, 30, 22 and 28 during year 2010-11 while for 2011-12 were 20, 33, 27 and 28.
Coefficient of variance for E-T, T-SE and B-A was quite good ranging from 0 to $6.7 \%$ but the coefficient of variance of calendar days for SE-B was a little bit high $(14.4 \%)$. Thermal time calculated for E-T, T-SE, SE-B and B-A was 217, 178, 153 and 252 for 2010-11 and 237, 174,152 and 231 for year 2011-12 with a very low coefficient of variance ranging from 0.5 to $6.2 \%$. Photothermal time for these stages was recorded to be 28, 22, 22 and $47^{\circ} \mathrm{C}$ days for year 2010-11 and 3121,22 and 47 for year 2011-12 with very small variation ranging from 0.5 to $7.3 \%$. For grain formation stage (AnthesisPhysiological Maturity), calendar days, thermal time and photo-thermal was observed to be 28, 444 and 112 for year 2010-11 and almost same for the year 2011-12 (28, 442 and 112). Over all, calendar days for sowing to physiological maturity (S-PM) were 138 and 143 for both study years. Thermal time (1345 vs 1341) and photothermal time (245 vs 249 ) for the entire growing season was found to be very close for both years. 
Table 2. Calendar, Thermal and Photo-thermal Time for different developmental phases of Wheat cv Sehar-2006 in Faisalabad

\begin{tabular}{|c|c|c|c|c|c|c|c|c|c|}
\hline \multirow{3}{*}{$\begin{array}{l}\text { Growth } \\
\text { Stage }\end{array}$} & \multicolumn{6}{|c|}{ Year } & \multirow{2}{*}{\multicolumn{3}{|c|}{ Average (with \% CV) }} \\
\hline & & 2010-1 & & & 2011-12 & & & & \\
\hline & $\begin{array}{c}\text { Calendar } \\
\text { Time } \\
\text { (days) }\end{array}$ & $\begin{array}{l}\text { Thermal } \\
\text { Time } \\
\left({ }^{\circ} \mathrm{C} \text { days }\right)\end{array}$ & $\begin{array}{c}\text { Photothermal } \\
\text { Time } \\
\left({ }^{\circ} \mathrm{C} \text { days }\right)\end{array}$ & $\begin{array}{c}\text { Calendar } \\
\text { Time } \\
\text { (days) }\end{array}$ & $\begin{array}{l}\text { Thermal } \\
\text { Time } \\
\left({ }^{\circ} \mathrm{C} \text { days }\right)\end{array}$ & $\begin{array}{c}\text { Photothermal } \\
\text { Time } \\
\left({ }^{\circ} \mathrm{C} \text { days }\right)\end{array}$ & $\begin{array}{c}\text { Calendar } \\
\text { Time } \\
\text { (days) }\end{array}$ & $\begin{array}{l}\text { Thermal } \\
\text { Time } \\
\left({ }^{\circ} \mathrm{C} \text { days }\right)\end{array}$ & $\begin{array}{c}\text { Photothermal } \\
\text { Time } \\
\left({ }^{\circ} \mathrm{C} \text { days }\right)\end{array}$ \\
\hline S-E & 8 & 101 & 14 & 7 & 105 & 15 & $8(9.4)$ & $103(2.8)$ & $15(2.8)$ \\
\hline E-T & 22 & 217 & 28 & 20 & 237 & 31 & $21(6.7)$ & $227(6.2)$ & $29(7.3)$ \\
\hline T-SE & 30 & 178 & 22 & 33 & 174 & 21 & $32(6.7)$ & 176 (1.6) & $22(1.0)$ \\
\hline SE-B & 22 & 153 & 22 & 27 & 152 & 22 & 25 (14.4) & $153(0.5)$ & $22(0.9)$ \\
\hline B-A & 28 & 252 & 47 & 28 & 231 & 47 & $28(0)$ & $242(6.1)$ & $47(0.5)$ \\
\hline A-PM & 28 & 444 & 112 & 28 & 442 & 112 & $28(0)$ & $443(0.3)$ & $112(0.1)$ \\
\hline S-PM & 138 & 1345 & 245 & 143 & 1341 & 249 & $141(2.5)$ & $1343(0.2)$ & $247(1.0)$ \\
\hline
\end{tabular}

Where $\mathrm{S}=$ Sowing, E= Emergence, $\mathrm{T}=$ Tillering, $\mathrm{SE}=$ Stem Elongation, $\mathrm{B}=$ Booting , A= Anthesis, PM= Physiological Maturity

\section{Growth}

Table 3 shows the statistical analysis of maximum LAI at 90 days after sowing (Booting stage). Effect of fertilizer on maximum LAI was significant in year 2010-11 and highly significant in year 2011-12. $F_{2}$ and $F_{3}$ produced statistical same LAI but significantly higher as compared to low fertilizer rate $\left(F_{1}\right)$ in both years. The effect of irrigation scheduling on LAI was highly significant in both years. In year 2010-11, full irrigation $\left(\mathrm{I}_{1}\right)$ and no stress at early and middle growth stages $\left(\mathrm{I}_{4}\right)$ produced statistically same LAI that was higher as compared to other treatments.

Table 3. Effect of Irrigation and Fertilizer on maximum LAI, LAD and mean CGR of Wheat

\begin{tabular}{|c|c|c|c|c|c|c|c|c|c|}
\hline \multirow[t]{3}{*}{ Treatments } & \multicolumn{3}{|c|}{ Max LAI } & \multicolumn{3}{|c|}{$\begin{array}{c}\text { Mean CGR } \\
\left(\mathrm{g} \mathrm{m}^{-2} \mathrm{~d}^{-1}\right)\end{array}$} & \multicolumn{3}{|c|}{$\begin{array}{c}\text { Grain Yield } \\
\left(\mathrm{kg} \mathrm{ha}^{-1}\right)\end{array}$} \\
\hline & \multicolumn{3}{|c|}{ Year } & \multicolumn{3}{|c|}{ Year } & \multicolumn{3}{|c|}{ Year } \\
\hline & 2010-11 & 2011-12 & Average & 2010-11 & 2011-12 & Average & $2010-11$ & $2011-12$ & Average \\
\hline $\mathrm{F}_{1}$ & $3.56 \mathrm{~b}$ & $3.84 \mathrm{~b}$ & 3.75 & $7.78 \mathrm{c}$ & $8.34 \mathrm{~b}$ & 8.06 & $2385 \mathrm{~b}$ & $2927 \mathrm{~b}$ & 2656 \\
\hline $\mathrm{F}_{2}$ & $4.21 \mathrm{a}$ & $4.73 \mathrm{a}$ & 4.47 & $9.38 \mathrm{~b}$ & $9.14 \mathrm{a}$ & 9.26 & $3100 \mathrm{a}$ & $3265 \mathrm{a}$ & 3182 \\
\hline $\mathrm{F}_{3}$ & $4.64 \mathrm{a}$ & $5.18 \mathrm{a}$ & 4.91 & $10.28 \mathrm{a}$ & $9.50 \mathrm{a}$ & 9.89 & $3451 \mathrm{a}$ & $3417 \mathrm{a}$ & 3434 \\
\hline LSD & 0.63 & 0.63 & & 0.33 & 0.55 & & 355 & 243 & \\
\hline Significance & $*$ & $* *$ & & $* *$ & $* *$ & & $* *$ & $*$ & \\
\hline $\mathrm{I}_{1}$ & $4.97 \mathrm{a}$ & $5.46 \mathrm{a}$ & 5.21 & $10.89 \mathrm{a}$ & $12.66 \mathrm{a}$ & 11.78 & $3735 \mathrm{a}$ & $4603 \mathrm{a}$ & 4169 \\
\hline $\mathrm{I}_{2}$ & $3.40 \mathrm{c}$ & $3.43 \mathrm{~b}$ & 3.41 & $8.44 \mathrm{c}$ & $7.50 \mathrm{~d}$ & 7.97 & $2832 \mathrm{~cd}$ & $2651 \mathrm{~d}$ & 2741 \\
\hline $\mathrm{I}_{3}$ & $4.41 \mathrm{~b}$ & $5.22 \mathrm{a}$ & 4.82 & $9.67 \mathrm{~b}$ & $9.50 \mathrm{c}$ & 9.59 & $3425 \mathrm{ab}$ & $3405 \mathrm{c}$ & 3415 \\
\hline $\mathrm{I}_{4}$ & $4.72 \mathrm{a}$ & $5.33 \mathrm{a}$ & 5.03 & $10.00 \mathrm{~b}$ & $10.84 \mathrm{~b}$ & 10.42 & $3161 \mathrm{bc}$ & $3853 \mathrm{~b}$ & 3507 \\
\hline $\mathrm{I}_{5}$ & $4.17 \mathrm{~b}$ & $5.12 \mathrm{a}$ & 4.56 & $8.33 \mathrm{~cd}$ & $7.06 \mathrm{~d}$ & 7.70 & $2523 \mathrm{de}$ & $2478 \mathrm{~d}$ & 2501 \\
\hline $\mathrm{I}_{6}$ & $3.15 \mathrm{c}$ & $3.15 \mathrm{~b}$ & 3.15 & $7.56 \mathrm{~d}$ & $6.39 \mathrm{e}$ & 6.98 & $2195 \mathrm{e}$ & $2229 d$ & 2212 \\
\hline LSD & 0.27 & 0.37 & & 0.88 & 0.62 & & 333 & 446 & \\
\hline Significance & $* *$ & $* *$ & & $* *$ & $* *$ & & $* *$ & $* *$ & \\
\hline Interaction & ns & ns & & ns & ns & & $\mathrm{ns}$ & $\mathrm{ns}$ & \\
\hline Mean & 4.14 & 4.62 & & 9.15 & 8.99 & & 2978 & 3203 & \\
\hline
\end{tabular}

Mean sharing different letters in a column differ significantly at $\mathrm{p} \leq 0.05^{*}, * *=$ significant and highly significant respectively; NS $=$ Non-Significant, $\mathrm{LSD}=$ least significant difference

$\mathrm{I}_{2}$ (early stage drought) and $\mathrm{I}_{6}$ (early and last stage drought) produce statistically same LAI but lower from all other treatments. Performance of irrigation scheduling in year 2011-12 showed a slightly different trend. Stress at early stage $\left(\mathrm{I}_{2}\right)$ and early and late stage $\left(\mathrm{I}_{6}\right)$ produced low but statistically same LAI and all other treatments $\left(\mathrm{I}_{1}, \mathrm{I}_{3}, \mathrm{I}_{4}\right.$ and $\mathrm{I}_{6}$ ) produced statistically same LAI at 90 days after sowing but after that there were greater differences in LAI among treatments with the passage of time as LAI dropped down.

$F_{2}$ and $F_{3}$ produced statistically same LAI 4.64 and 4.21 in $2010-11$ and 5.18 vs 4.73 in $2011-12$ which was significantly higher than $F_{1}$ (3.56 and 3.84). Interactive effect of fertilizer and irrigation on LAI was nonsignificant for both years. 


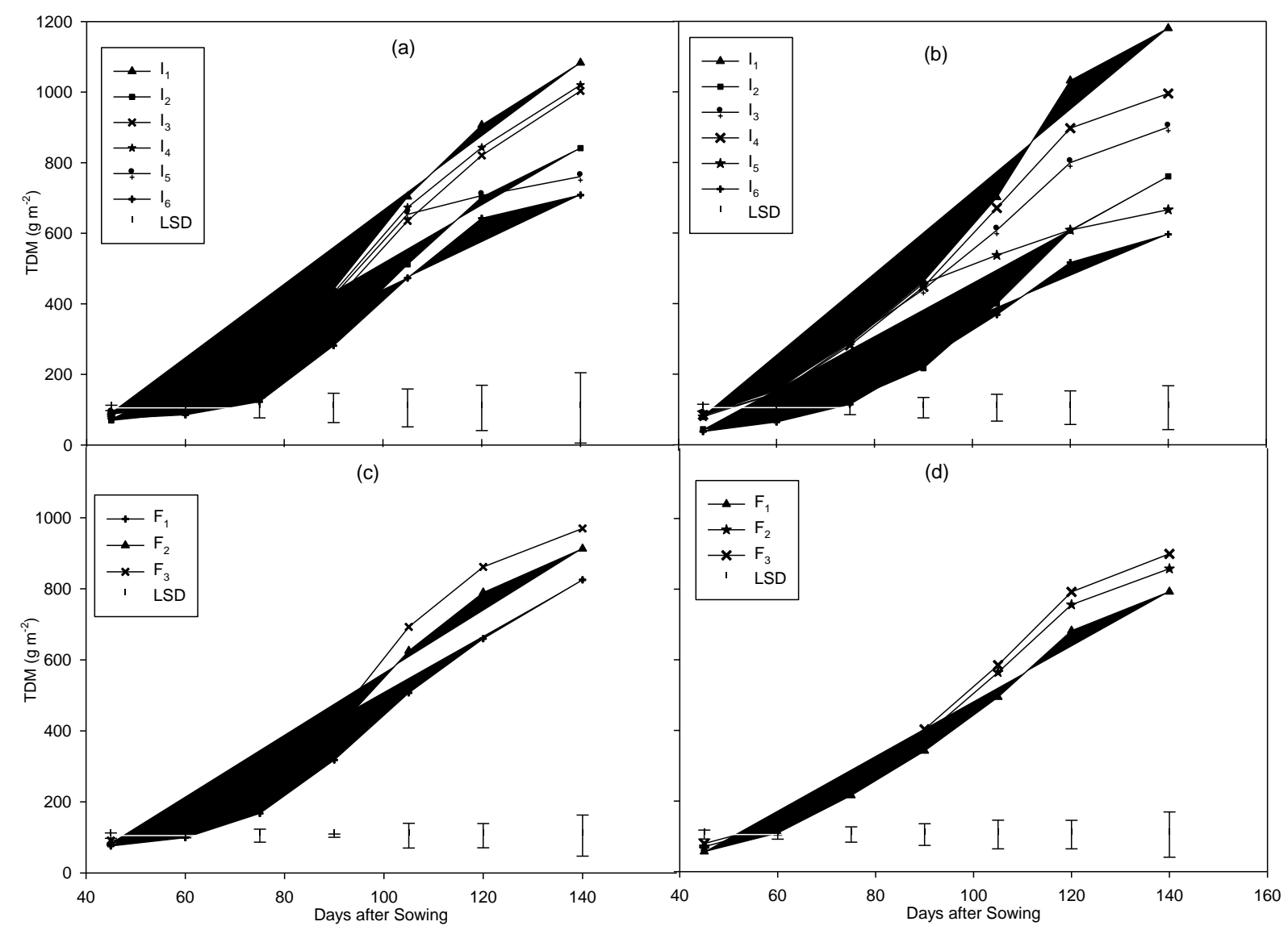

Figure 2. TDM accumulation in wheat as affected by Irrigation in 2010-11 (a) and 2011-12 (b) and Fertilizer in 2010-11 (c) and 2011-12 (d).

Fig2 shows time series analysis of dry matter accumulation for year 2010-11 and 2011-12. At earlier growth stages, TDM accumulation was at a quite low rate due to lag period. After 75 days of sowing, rate of TDM accumulation was accelerated. Throughout the growing season, accumulated TDM was low in treatments having irrigation stress at early growth stages $\left(\mathrm{I}_{2}\right.$ and $\left.\mathrm{I}_{6}\right)$. TDM accumulation was maximum in treatments having no drought stress $\left(\mathrm{I}_{1}\right)$ followed by treatment with water stress at late growth stage $\left(\mathrm{I}_{4}\right)$. Dry matter accumulation in $\mathrm{F}_{3}$ was maximum, followed by $F_{2}$ while $F_{1}$ produced least dry matter.

Table 3 shows the data for mean crop growth rate (CGR) during year 2010 and 2011. For both years, effect of fertilizer and irrigation was highly significant while their interaction was non-significant. For year 2010-11, $\mathrm{F}_{3}$ showed statistically higher CGR (11.74 $\left.\mathrm{g} \mathrm{m}^{-2} \mathrm{~d}^{-1}\right)$ and $\mathrm{F}_{1}$ produced significantly low CGR $\left(9.05 \mathrm{~g} \mathrm{~m}^{-2} \mathrm{~d}^{-1}\right)$. In year 2011-12, performance of $F_{2}$ and $F_{3}$ for CGR (9.14 and $\left.9.50 \mathrm{~g} \mathrm{~m}^{-2} \mathrm{~d}^{-1}\right)$ was statistically at par but significantly higher than $F_{1}\left(8.34 \mathrm{~g} \mathrm{~m}^{-2} \mathrm{~d}^{-1}\right)$.

In year 2010-11, CGR was high in $\mathrm{I}_{1}\left(10.89 \mathrm{~g} \mathrm{~m}^{-2} \mathrm{~d}^{-1}\right)$ while $\mathrm{I}_{6}$ yielded low CGR $\left(7.56 \mathrm{~g} \mathrm{~m}^{-2} \mathrm{~d}^{-1}\right)$ which was statistically at par with $\mathrm{I}_{5}\left(8.33 \mathrm{~g} \mathrm{~m}^{-2} \mathrm{~d}^{-1}\right)$. In year 2011-12, Full irrigation $\left(\mathrm{I}_{1}\right)$ treatment produced significantly high CGR (12.66 $\left.\mathrm{g} \mathrm{m}^{-2} \mathrm{~d}^{-1}\right)$ while $\mathrm{I}_{6}$ yielded significantly low CGR $\left(6.39 \mathrm{~g} \mathrm{~m}^{-2} \mathrm{~d}^{-1}\right)$.

\section{Yield}

Data regarding grain yield is presented in Table 3. Response of grain yield from low to higher fertilizer was highly significant in year 2010-11 and significant in year 2011-12. Grain yield showed highly significant response to irrigation in both years. In both years, $F_{2}$ and $F_{3}$ produced statistical similar grain yield but significantly higher than low fertilizer rate $\left(\mathrm{F}_{1}\right)$. During first year experiment, full irrigation $\left(\mathrm{I}_{1}\right)$ translated maximum dry matter into grain yield (3735 $\left.\mathrm{kg} \mathrm{ha}^{-1}\right)$ and it was statistically at par with $\mathrm{I}_{3}\left(3425 \mathrm{~kg} \mathrm{ha}^{-1}\right)$. Performance of $\mathrm{I}_{6}$ $\left(2195 \mathrm{~kg} \mathrm{ha}^{-1}\right)$ and $\mathrm{I}_{5}\left(2523 \mathrm{~kg} \mathrm{ha}^{-1}\right)$ was statistically low and at par with each other. In 2011-12, maximum transformation of photosynthates into economical part of plant in the form of grain yield $\left(4603 \mathrm{~kg} \mathrm{ha}^{-1}\right)$ was noted in full irrigation treatment $\left(\mathrm{I}_{1}\right)$ and treatments having drought stress at tillering and grain formation $\left(\mathrm{I}_{2}, \mathrm{I}_{5}\right.$ and $\left.\mathrm{I}_{6}\right)$ resulted in significantly low grain yield $(2651,2478$ and $\left.2229 \mathrm{~kg} \mathrm{ha}^{-1}\right)$. 

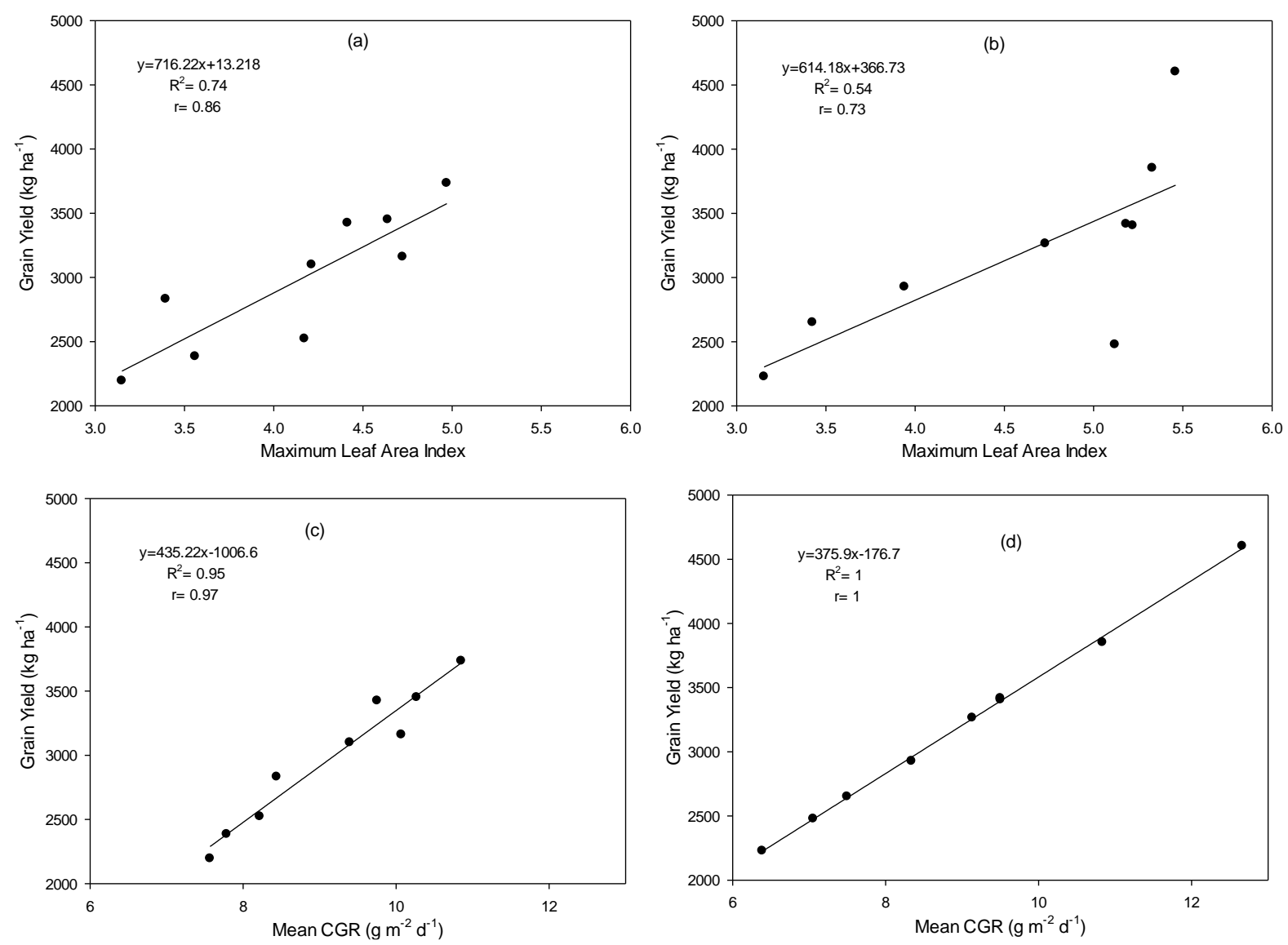

Figure 3. Relationship of Grain Yield with maximum LAI in 2010-11 (a) and 2011-12 (b) and mean CGR in $2010-11$ (c) and 201112 (d).

Fig-3 illustrates the relationship between maximum leaf area index and grain yield observed in 2010-11 and 2011-12. The correlation between maximum LAI and grain yield was strong $(0.86$ and 0.73$)$ with a good coefficient of determination $\left(\mathrm{R}^{2}=0.74\right.$ and 0.54$)$ for years 2010-11 and 2011-12 respectively. Similarly, the relationship of grain yield with LAD (Fig 3), was observed to be very good ( $\mathrm{r}=0.85$ and 0.83 ) with strong dependence $\left(R^{2}=0.73\right.$ and 0.70$)$ for year $2010-11$ and 2011-12 respectively. Fig-2 shows that grain yield and mean CGR were positively correlated $(\mathrm{r}=0.91$ and 1$)$ with a very strong dependence $\left(R^{2}=0.94\right.$ and 1$)$ of yield on mean crop growth rate.

\section{DISCUSSION}

Irrigation and nitrogen management practices produced a considerable effect on phenology (calendar days, thermal time and photo-thermal time), growth (LAI, TDM accumulation) and yield of wheat crop in semi-arid conditions of Pakistan. Phenology is the onset of different growth stages driven by the genetic as well as meteorological factors (Ma et al., 2011). Different calendar days of growing season length depict the exposure of crop to different weather conditions particularly minimum and maximum temperature. It is actually the accumulated thermal time and photo-thermal time that directs the crop to shift to the next growth stage
(Xiao et al., 2013). When the required thermal time and photo-thermal is completed, crop switches to physiological maturity and completes its growing cycle. In year 2011-12, comparatively higher temperature at early growth stages (emergence and tillering) switch the crop to next development phase in less calendar days (7 vs 8,20 vs 22) as compared to that in 2010-11. Cooler temperature at stem elongation and booting stage increased its calendar days by 3 and 5 for respective stage to complete their required growing degree days and switch to next stage in 2011-12 as compared to 2010-11. These results are in a good agreement with the findings of Saiyed et al. (2008) who stated that crop phenology is a function of growing degree days (GDD).

Leaf area is dependent upon rate and duration of leaf expansion which is very sensitive to water and nitrogen availability. Water stress at early growth stage $\left(\mathrm{I}_{2}\right.$ and $\left.\mathrm{I}_{5}\right)$ resulted in lower LAI. Water shortage reduced nutrient availability and subsequently photosynthesis process (Jazy et al., 2007). Plant attained maximum LAI at 90 DAS, after that water stress have no prominent impact on LAI. In 2011-12, climatic conditions (comparatively cool temperature and slightly low temperature) were more favorable for crop growth. So, maximum LAI was higher as compared to that in 2010-11. Optimum nitrogen availability $\left(F_{2}\right.$ and $\left.F_{3}\right)$ enhanced assimilates accumulation 
and leaf expansion (Hammad et al., 2011) that finally boosted crop LAI (Awais et al., 2013). The crop plants suffered from nitrogen deficiency with low fertilizer $\left(F_{1}\right)$ subsequently reduced photosynthesis rate that finally resulted in lower LAI (Bavec et al., 2007).

Optimum irrigation application treatments increased TDM accumulation by enhancing crop CGR. Reduced TDM production in water stress treatments may be due to unstable plant-soil-water relations which led to decreased photosynthetic rate. The response of fertilizer to TDM accumulation was almost in a similar pattern in both years throughout the growing season. Low fertilizer rate $\left(\mathrm{F}_{1}=80\right.$ $\mathrm{kg} \mathrm{ha} \mathrm{h}^{-1}$ ) yielded statistically low dry matter because growth was limited due to nitrogen stress (Awais et al., 2015; Zhang et al., 2016). Nitrogen stress resulted in lower LAI and ultimately low dry matter (Xiao et al., 2009). More light capture due to higher leaf chlorophyll contents, increased leaf area and broader plant leaves in response of higher fertilizer rate finally enhanced TDM accumulation (Fan et al., 2005).

Optimum irrigation application produces a positive effect on crop CGR (Thakuria et al. 2004). Plants without drought stress attained higher mean CGR while drought stress at grain formation significantly declined mean crop growth rate. But moisture stress at tillering stage has drastic effect on biomass and produced least mean crop CGR (Santos et al., 2007). CGR, being a function of LAI (Hammad et al., 2011) enhanced with fertilizer application. Higher CGR with nitrogen fertilizer application may be due to a major role of this nutrient in cell formation its elongation and chlorophyll production.Economical part harvested from plant, grain yield, is of prime importance. The increase in grain yield with increase in nitrogen rate is due to its higher leaf area expansion, more interception of sun light, higher biomass production and higher efficiency of the transformation of biomass into economical product (Zhang et al., 2016). Nutrients availability is associated with the soil moisture. Full irrigation has abundant soil moisture throughout the growing season, ensuring the availability of nutrients particularly nitrogen to the plants and helping them to perform better to attain maximum grain yield (Bashir et al., 2016; Sarwar et al., 2010). Water stress at early growth stage reduces LAI and cop growth rate which have negative effect on grain yield. Water stress at late growth stage (grain formation) reduces the efficiency of transformation of accumulated dry matter into economical yield of the plant (Ali et al., 2007).

\section{CONCLUSIONS}

Wheat development, growth and yield responded significantly to different nitrogen levels and irrigation scheduling (based on critical growth stages). Full irrigation and no fertilizer stress resulted in optimum utilization of resources. Our study recommends the farmers to use $120 \mathrm{~kg} \mathrm{ha}^{-1}$ nitrogen and avoid excessive use of nitrogen $\left(\mathrm{F}_{3}: 160 \mathrm{~kg} \mathrm{ha}^{-1}\right)$ because it performed statistically similar to $F_{2}$. In full water availability, irrigation at tillering, stem elongation, booting and grain formation is recommended for maximum yield. In case of water shortage, irrigation at tillering is strongly recommended to reduce drastic loss in biomass and grain yield.

\section{ACKNOWLEDGEMENT}

First author is highly thankful to Higher Education Commission, Pakistan for financial assistance in the form of Indigenous 5000 PhD Fellowship Program.

\section{LITERATURE CITED}

AL-Harbi, A.R., A.M. Al-Omran, M.M. Alenazi and M.A. Wahb-Allah. 2015. Salinity and deficit irrigation influence tomato growth, yield and water use efficiency at different developmental stages. Intl. J. Agric. Bio. 17(2): 241-250.

Ali, M. H., M.R. Hoque, A.A. Hassan and A. Khair. 2007. Effects of deficit irrigation on yield, water productivity, and economic returns of wheat. Agric. water Management. 92: $151-161$

Awais, M., A. Wajid, A. Ahmad, M.F. Saleem, M.U. Bashir, U. Saeed, J. Hussain and M. Habib-Ur-Rahman. 2015. Nitrogen fertilization and narrow plant spacing stimulates sunflower productivity. Turkish J. Field Crops. 20(1): 99-108.

Awais, M., A. Wajid, W. Nasim, A. Ahmad, M.F. Saleem, M.A.S. Raza, M.U. Bashir, M. Habib-ur-Rahman, U. Saeed, J. Hussain, N. Arshad and G. Hoogenboom. 2017. Modeling the water and nitrogen productivity of sunflower using OILCROP-SUN model in Pakistan. Field Crops Res. 205:67-77.

Awais, M., A.Wajid, A. Ahmad and A. Bakhsh.2013. Narrow plant spacing and nitrogen application enhances sunflower (Helianthus annuusL.) productivity. Pak. J. Agri. Sci. 50(4): 689-697.

Bashir, M.U., S.A. Wajid, A. Ahmad and M. Iqbal. 2016. Potential Soil Moisture Deficit: An Alternative Approach for Irrigation Scheduling in Wheat. Intl. J. Agric.Bio. 18(1): 1622.

Bavec, M., K. Vuković, S.G. Mlakar, C. Rozman and F. Bavec. 2007. Leaf area index in winter wheat: response on seed rate and nitrogen application by different varieties. J. Central Europ. Agric. 8(3): 337-342.

Behera, S.K. and R.K. Panda. 2009. Effect of fertilization and irrigation schedule on water and fertilizer solute transport for wheat crop in a sub-humid sub-tropical region. Agric. Ecosystems Environ. 130: 141-155.

Du, T., S. Kang, J. Sun, X. Zhang and J. Zhang. 2010. An improved water use efficiency of cereals under temporal and spatial deficit irrigation in north China. Agric. Water Management. 97: 66-74.

Dumont, B., B. Basso, B. Bodson, J.P. Destain and M.F. Destain. 2016. Assessing and modeling economic and environmental impact of wheat nitrogen management in Belgium. Environ. Modelling Software. 79: 184-196. doi:10.1016/j.envsoft.2016.02.015

Fan, M., R. Jiang, X. Liu, F. Zhang, S. Lu, X. Zeng and P. Christie. 2005. Interactions between Non-Flooded Mulching Cultivation and Varying Nitrogen Inputs in Rice-Wheat Rotations," Field Crops Res. 91:307-318.

FAO. 1978. Agro-ecological zones. Report on the project, Vol. 1. Methodology and results for Africa, Rome.

Gallagher, J.N., P.V. Biscoe and R.D. Jones. 1983. Environmental influence on the development, growth and yield of barley. In: Barley Production and Marketing. Agron. Soc. New Zealand. Special Publication No. 200 PP. 21-50

GOP. 2014. Economic survey of Pakistan. pp 34. 
Hammad, H.M., A. Ahmad, A. Wajid and J. Akhter. 2011. Maize response to time and rate of nitrogen application. Pak. J. Bot. 43:1935-1942.

Hunt, R. 1978. Plant growth analysis. Edward Arnold, U.K., PP: 26-38.

Jazy, H.D., M.R. Poor, H.H. Abad and A. Soleimani. 2007. Growth indices of winter wheat as affected by irrigation regimes under Iran conditions. Pak. J. Bio. Sci. 10 (24): 4495-9.

Karousakis, K. and P. Koundouri. 2006. Water management in arid and semi-arid regions: Interdisciplinary perspectives-an introduction. P. Koundouri, K. Karousakis, D. Assimacopoulos, P. Jeffrey, M.A. Lange (Eds.). Edward Elgar Publishing, Inc. USA. pp 3-13.

Liu, J., J.R. Williams, A.J.B. Zehnder and H. Yang. 2007. GEPIC - modelling wheat yield and crop water productivity with high resolution on a global scale. Agric. Systems. 94: 478-493.

Ma, S., G. Churkina and K. Trusilova. 2012. Investigating the impact of climate change on crop phenological events in Europe with a phenology model. Intl. J. Biometeorol. 56(4): 749-63. doi: 10.1007/s00484-011-0478-6

Saiyed, I.M., P.R. Bullock, H.D. Sapirstein, G.J. Finlay and C.K. Jarvis. 2008. Thermal time models for estimating wheat phonological development and weather-based relationships to wheat quality. Canadian J. Plant Sci. 88: 429-439.

Santos, T.P.D., C.M. Lopes, M.L. Rodrigues, C.R. de Souza, J.M. Ricardo-da-Silva, J.P. Maroco, J.S. Pereira and M.M. Chaves. 2007. Effects of deficit irrigation strategies on cluster microclimate for improving fruit composition of Moscatel field-grown grapevines. Scientia Horticulturae, 112: $321-330$
Sarwar, N., M. Maqsood, K. Mubeen. M. Shehzad, M.S. Bhullar, R. Qamar and N. Akbar. 2010. Effect of different levels of irrigation on yield and yield components of wheat cultivars. Pak. J. Agric. Sci. 47: 371-374.

Thakuria, R.K., S. Harbir and S. Tej. 2004. Effect of irrigation and antitranspirants on growth and yield of spring sunflower (Helianthus annuus L.). Ann. Agric. Res. 25:433-438.Awais, M., A. Wajid, A. Ahmad, F. Saleem, M.U. Bashir, U. Saeed, J. Hussain and H.U. Rehman. 2015. Nitrogen fertilization and narrow plant spacing stimulates sunflower productivity. Turkish J Field Crops. 20(1): 99-108.

Xiao, D., F. Tao, Y. Liu, W. Shi, M. Wang, F. Liu, S. Zhang and Z. Zhu. 2013. Observed changes in winter wheat phenology in the North China Plain for 1981-2009. Intl. J. Biometeorol. 57(2): 275-85. doi: 10.1007/s00484-012-05528.

Xiao, G., Q. Zhang, R. Wang and Y. Xiong. 2009. Effects of elevated $\mathrm{CO}_{2}$ concentration, supplemental irrigation and nitrogenous fertilizer application on rain-fed spring wheat yield. Acta Ecologica Sinica. 29: 205-210.

Zhang, Y., X. Dai, D. Jia, H. Li, Y. Wang, C. Li, H. Xu and M. He. 2016. Effects of plant density on grain yield, protein size distribution, and breadmaking quality of winter wheat grown under two nitrogen fertilisation rates. European J. Agron. 73: 1-10. doi:10.1016/j.eja.2015.11.015 